\title{
La imagen de D. Pedro y D. Miguel en la novela histórica portuguesa del siglo XIX
}

\author{
Beatriz Peralta García \\ Universidad de Oviedo \\ The image of D. Pedro and D. Migel in the Portuguese historical
novel of XIX Century
}

RESUMEN SUMMARY

La revolución liberal en Portugal tuvo su reflejo en la literatura de la segunda mitad del siglo xix. La novela histórica de actualidad aborda los acontecimientos políticos más importantes con el objetivo de consolidar el nuevo estado liberal tras los enfrentamientos con los absolutistas. La imagen que de los infantes D. Pedro, liberal, y D. Miguel, absolutista, se

difunde, caracteriza con éxito a ambos personajes, creando un estereotipo que se mantiene hasta la actualidad. El objetivo del trabajo es analizar los diferentes procesos que se utilizan para la identificación de esta figuras así como su trasfondo político.

PALABRAS CLAVE revolución liberal en Portugal, novela histórica de actualidad, D. Pedro, D. Miguel
The liberal revolution in Portugal had his reflex in the literature of the second half of the xixth century. The historical novel of current importance approaches the most important political events with the aim(lens) to consolidate the new liberal condition(state) after the clashes with the absolutists. The image that of the infantes D. Pedro, liberal, and D. Michael, absolutist, spreads, characterizes successfully both prominent figures, creating a stereotype that is kept up to the current importance. The aim(lens) of the work is to analyze the different processes that are in use for the identification of this one you appear as well as his political background.

KEY WORDS

liberal revolution in Portugal, historical novel of current importance, D. Pedro, $D$. Michael 


\section{POLÍTICA Y LITERATURA EN LA SEGUNDA MITAD DEL SIGLO XIX}

Desde los años 80 del pasado siglo xx, especialistas procedentes tanto del ámbito de la literatura como de la historia vienen reivindicando el uso de textos literarios como fuente para la investigación histórica ${ }^{1} \mathrm{y}$, en este sentido, publicaciones recientes confirman la idoneidad de su uso en la reconstrucción del pasado. ${ }^{2}$ Completan y aportan información sobre aspectos como la percepción de la realidad desde la perspectiva contemporánea, con mucha más expresividad que la documentación institucional, más fría. Por ello, resultan especialmente interesantes para el estudio de las mentalidades. Para el caso que nos ocupa, la imagen que se transmite de los infantes $\mathrm{D}$. Pedro y $\mathrm{D}$. Miguel hay que rastrearla, también, en la novela del siglo XIX, que relata el período histórico comprendido entre las invasiones napoleónicas y la consolidación del régimen liberal en Portugal. En síntesis, los acontecimientos políticos son los siguientes.

Tras la firma del Tratado de Fontaineblau, que prevé el reparto de Portugal, Junot invade el territorio lusitano en octubre de $1807 \mathrm{y}$, a finales de noviembre se apodera de Lisboa. El día antes, la familia real portuguesa había partido hacia su exilio en el Brasil.

La soberanía regia del país se mantiene con el nombramiento de un Consejo de Regencia, que está compuesto por nueve miembros escogidos de entre la nobleza, el clero y la magistratura, mientras en términos militares Portugal queda bajo protección inglesa al mando del general Beresford, que comienza a ser una figura incómoda para los gobernadores, descontentos con la ingerencia británica en asuntos internos. Pero al mismo tiempo que estos gobernadores promueven un cierto sentimiento nacional y anti-británico, reprimen cualquier intentona de transformación política. Las conspiraciones a favor de las ideas liberales aparecen vinculadas a las sociedades secretas, que favorecen dos movimientos: el de Gomes Freire en 1817 y, el vinculado al Sinédrio en 1818, que llevará al estallido revolucionario de 24 de agosto de 1820. Ese día, un golpe militar en Oporto lleva a la formación de una Junta de Gobierno. La revolución emprende la marcha hacia Lisboa y, en octubre triunfa también aquí.

Junto a la convocatoria de Cortes Generales Extraordinarias y Constituyentes, una de las primeras medidas que los liberales abordan es la cuestión del regreso del rey, tema ampliamente debatido. Pero en Brasil los acontecimientos que con-

1 Vid. a este respecto los trabajos de MAINER, J. C., «Literatura y sociedad desde 1898. Estado de la cuestión", en TUÑón DE LARA, M., Historiografía española contemporánea, Madrid, ed. Siglo XXI, 1980; Jover ZAMORA, J. M., «De la literatura como fuente histórica», Boletín de la Real Academia de la Historia, Tomo CLXXXIX - Cuaderno 1, enero-abril, Madrid, 1992, págs. 23-42.

2 Peralta García, B., «El teatro como fuente para la historia de la cultura obrera en Portugal», $R e-$ vista de Historiografía. Historiografía de la historia social. Tendencias historiográficas y didáctica de la Historia, n. ${ }^{2}$, II (1/2005), págs. 136-142; NIETo FERRANDO, J. J., «Literatura e Historia. De la «Función social» de la literatura a su futuro como «documento histórico» a partir de Juan Goytisolo», GonzÁLEZ CALLEJA, E. (Ed.), Juventud y Política en la España Contemporánea, Ayer 59/2005 (3), págs. 233-257. 
ducen a la independencia de la colonia de la antigua metrópoli provocan la fractura del regreso de los miembros de la familia real en abril de 1821. El infante D. Pedro permanece en Brasil, convirtiéndose en emperador en 1822.

En Portugal, el movimiento conspirativo para volver al sistema anterior a la revolución de 1820 se desarrolla desde 1822 y, tiene en la reina D. ${ }^{a}$ Carlota Joaquina y en su hijo, el infante D. Miguel, a sus principales valedores. Esta circunstancia, a la que se une el problema político causado por la independencia brasileña, hace que el rey $D$. João VI marque los límites de su sucesión, trasladando la regencia de la reina a su hija la infanta $D .{ }^{a}$ Isabel Maria, que la asume de forma efectiva en 1826 , tras la muerte del monarca.

Desde el Brasil, D. Pedro, ahora convertido en rey de Portugal, envía la Carta Constitucional, que es mal recibida por los sectores absolutistas. Este hecho, unido al problema sucesorio que plantea la renuncia del rey a favor de su hija, la infanta D. ${ }^{a}$ Maria da Glória, desencadena una crisis política entre 1826 y 1827 . A finales de año, el infante $D$. Miguel inicia su regreso, aunque previamente ha jurado la Carta en Viena y aceptado la situación diseñada por D. Pedro sobre su papel político en Portugal. Llega en febrero de 1828 con el ánimo de cumplir los deseos de su hermano: sustitución del gobierno de regencia de la infanta D. ${ }^{a}$ Isabel Maria y casamiento con su sobrina, la futura heredera al trono, D. ${ }^{a}$ Maria II da Glória. D. Miguel asume la regencia, pero a partir de marzo las decisiones políticas que toma están encaminadas a devolver al país a un sistema de poder absoluto. Desde el exilio, los liberales comienzan a formular la tesis de la usurpación del poder, poniendo en duda la legitimidad de los actos cometidos por el infante. En el interior, la oposición al gobierno de D. Miguel hace que éste emprenda una dura represión, que se traduce en encarcelamientos y muertes por fusilamiento.

Entre 1828 y 1830 , la política miguelista se centra en su justificación de cara al exterior. Pero tras la revolución de 1830, la llegada de los ministerios liberales de Grey y Palmerston en Inglaterra y, el regreso a Portugal de D. Pedro en 1831, que había abdicado la corona brasileña en su hijo de cinco años D. Pedro de Alcântara, provocan una inversión de los acontecimientos. Instalado en la isla azoriana de Terceira, D. Pedro se autoproclama regente y nombra un gobierno liberal. Al mismo tiempo, organiza una escuadra militar que parte hacia el continente en 1832. Se inicia entonces una guerra civil que durará hasta 1834, cuando tras el desembarco de las tropas liberales en las playas de Mindelo, la ciudad de Oporto quede cercada durante casi un año. Con la caída de Oporto y la recuperación del país por los liberales, la Convenção de Évora-Monte ponía fin a la guerra y enviaba a D. Miguel a un exilio dorado en Austria.

Todos estos acontecimientos son novelados por intelectuales liberales a partir de la segunda mitad del siglo XIX, literariamente agotada la vertiente medieval de la novela histórica. Ésta había nacido de la mano de Alexandre Herculano y Almeida Garrett. Tras la experiencia del exilio, vivido en Inglaterra y Francia a causa de su filiación liberal, el regreso a Portugal, una vez recuperado el constitucionalismo en 
1838, se salda con la introducción de las nuevas corrientes culturales que circulan en Europa ${ }^{3}$. Con el Romanticismo se difunde la obra de Walter Scott ${ }^{4}$, que junto a la influencia de Víctor Hugo más tarde, dotan a la novela histórica portuguesa de su propia personalidad. La ambientación recreada prefiere los escenarios medievales, donde se desarrollan tramas caracterizadas por un tono melodramático y pedagógico al mismo tiempo. En la década de los años $40^{5}$ ambos autores publican O Bobo (1843), Eurico, o Presbítero (1844), Monge do Císter (1848), y O Arco de Sant'Ana (1845), respectivamente.

A la novedad y pujanza del género no son ajenos otros escritores, como Camilo Castelo Branco con Luta de Gigantes, O Judeu y O Senhor do Paço de Ninães, compuestas en la década de los años 60 , aunque será el conjunto de novelas publicadas entre 1874 y 1876 O Regicida, A Filha do Regicida y A Craveira da Mártir, donde su autor alcance una mayor perfección técnica ${ }^{6}$. Rebello da Silva da a la estampa Rausso por Homizidio en 1842 y Ódio Velho Não Cansa en 1848, Oliveira Marreca O Conde Soberano de Castela en 1844 y, Aires Pinto de Sousa $O$ Mestre de Calatrava en 1848. A ellos habría que añadir la obra de los novelistas portuenses, como João de Andrade Corvo y António José Coelho Lousada.

Junto a la novela histórica medieval se desarrolla la corriente de actualidad ${ }^{7}$ a caballo entre la novela de actualidad que se impone a partir de la década de los 50 y el relato histórico propiamente dicho. Se caracteriza por la introducción de la con-

3 Fidelino de Figueiredo proponía 1825, año de la publicación del poema de Almeida Garrett Camões, como límite inicial para la introducción del Romanticismo en Portugal. La crítica posterior ha corregido este extremo, retrasando la fecha a 1836 y situando sus años de vigencia hasta 1870. Vid. este debate en SENA, J. de, «Para uma definição peridiológica do Romantismo Português», en Colóquio do Centro de Estudos do século XIX. Estética do Romantismo em Portugal, Lisboa, Grémio Literário, 1974, pág. 69; SaRAIVA, A. J. y LoPES, Ó., «O Romantismo em Portugal» en História da Literatura Portuguesa, Porto, Porto editora, 17. a ed., 1996, pág. 665; FrançA, J. A., O Romantismo em Portugal, Lisboa, Livros Horizonte, 1990, pág. 8; REIS, C. y PIRES, M. N., História crítica da literatura portuguesa. Vol. V: O Romantismo, Lisboa, ed. Verbo, s.d.

${ }_{4}$ Aunque introducida de forma tardía en Portugal, la obra de Walter Scott se difunde a partir de 1836 en traducciones y reseñas periodísticas. Hasta 1842 se contabilizan dieciséis traducciones de su obra, trece antes de 1840 y son numerosas las referencias en periódicos y revistas como el Arquivo Popular (1837), Diário do Governo, en un artículo que Herculano publica en 1835, O Panorama (1838), la Revista Literária do Porto y la Revista Teatral (1840). Chaves, C. B., O Romance Histórico no Romantismo Português, Lisboa, ed. do Instituto de Cultura Portuguesa, 1979, nota n. ${ }^{\circ} 15$, pág. 82 . Sobre la introducción y divulgación de la obra de Walter Scott en Portugal, vid. del mismo autor «Walter Scott. Algumas notas

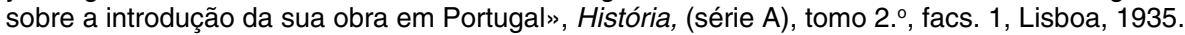

5 El profesor Júlio Taborda considera los años 40 la «época áurea» de la novela histórica medieval en Portugal. Taborda, J., Idade Média e Romantismo. Contribuição para o Estudo da Corrente Medievalista no Movimento Romântico Português, Universidade de Coimbra, 1972, pág. 148.

6 C. B. Chaves, O Romance Histórico..., op. cit., p. 54, considera que estas obras de Camilo Castelo Branco no pertenecen al género histórico en sentido estricto: «Miudências históricas, com «cor local» - em vão hão-de procurar nos romances históricos de Camilo. Tampouco atmosfera social e correspondência entre os personagens, na sua maneira de sentir e pensar, e a época em que o romancista os coloca». La misma opinión expresa Maria de Fátima MARINHO en O Romance Histórico em Portugal, Porto, Campo das Letras, ed., 1999, pág. 76.

7 BuESCU, H. C., «Narrativa histórica», Dicionário do Romantismo Literário Português, Lisboa, ed. Caminho, 1997, pág. 358. 
temporaneidad como escenario narrativo y por una especial factura pedagógica. El gusto por la ambientación en épocas recientes es una característica que ya apuntaban críticos como António Feliciano de Castilho ${ }^{8}$. A finales de la década de los años 40 se publican obras como Luiza e Júlia. Romance Histórico que Comprehende o Tempo do Dominio de Dom Miguel, (1845), de Francisco Pedro Celestino Soares, pionera en el género.

El objetivo que persiguen estos autores es doble: por un lado, evitar que el paso del tiempo haga caer en el olvido los acontecimientos más trágicos de la reciente historia portuguesa y, por otro, contribuir a la consolidación del liberalismo como forma de organización del Estado. Por eso, en las tramas de las novelas vamos a encontrar una exposición de la doctrina liberal que las aproxima casi a novelas de tesis. Las referencias de carácter político-constitucional son especialmente abundantes, con explicaciones sobre el funcionamiento del Estado y de sus instituciones, además de describir sus fundamentos teóricos y realizar una aguda crítica social. En el terreno de la composición de los personajes, los autores proceden a una caracterización maniquea que diferencia entre personajes positivos, los liberales, y personajes negativos, los absolutistas. Sin embargo, y en aras de contribuir al afianzamiento de las estructuras políticas liberales, los autores recuperan a aquellos afectos al absolutismo en términos sociales. El mensaje que se transmite es positivo, porque difunde la idea de construcción de un marco político convivencial y no excluyente.

\section{EL RETRATO LITERARIO}

La literatura ha fijado de forma indeleble la imagen de los infantes $D$. Pedro y D. Miguel, ambos hijos del rey D. João VI de Portugal y, de D. ${ }^{a}$ Carlota Joaquina, aunque también las de otros miembros de la familia real, como la de los reyes ya mencionados. Avanzado el siglo, Alberto Pimentel en O Arco de Vandôma (1916), alude a las figuras de la reina $D .{ }^{a}$ Maria II da Glória, a la que describe como «branca e nutrida» y, a su marido, el príncipe D. Fernando de Coburgo, «magro e esbelto". Junto a ellos, los hijos de ambos son los infantes D. Pedro, el heredero al trono, que es un joven de «ar grave, talvez melancólico» y, D. Luis, el duque de Oporto. Alberto Pimentel dibuja a D. Luis, en ese momento un chico de apenas 14 años de edad, como «rosado e loiro, muito loiro, quási um alemão, desembarazado nos gestos e nos olhares", una descripción que anuncia su futuro como monarca ante la prematura muerte de su hermano, el rey D. Pedro V ${ }^{9}$.

Por lo que respecta a los infantes D. Pedro y D. Miguel, su filiación liberal y absolutista, respectivamente, vendría a simbolizar la imagen del Portugal políticamente dividido en dos tendencias irreconciliables enfrentadas en una guerra cruen-

8 Castilho, A. F. de, Obras Completas, Vivos e Mortos, 7. ${ }^{\circ}$ tomo, pág. 88.

9 Vid. Pimentel, A., O Arco de Vandôma, Porto, Livraria Figueirinhas, 1945, pág. 280. 
ta. La victoria del liberalismo convertirá a $\mathrm{D}$. Pedro en un espejo de virtudes, mientras D. Miguel constituye el reverso absoluto de la medalla ${ }^{10}$. El propósito que anima a todos los autores es la consolidación del marco político del liberalismo. En este sentido, debemos considerar la figura de ambos infantes en tanto que personajes literarios, como representantes de una ideología concreta en un marco histórico preciso y definido. En nuestro análisis, nos detendremos en el estudio de las técnicas de caracterización que los autores utilizan para alcanzar su objetivo de proselitismo político.

\subsection{La caracterización nominal}

Los infantes D. Pedro y D. Miguel aparecen caracterizados con una doble nomenclatura: o con su título nobiliario o, con su nombre propio, como D. Pedro o D. Miguel, la forma de cortesía para los miembros de la familia real portuguesa. Sin embargo, para el uso de los títulos nobiliarios, es necesario tener en cuenta el momento histórico en el que la trama se desarrolla.

El infante D. Miguel detuvo la corona de Portugal de forma ilegal, según los liberales, desde 1828 y hasta 1834. De ahí que en Luiza e Júlia, cuyo argumento se desarrolla entre septiembre de 1827 y agosto de1834, aparezca bajo la denominación regia: “Vi o rei» ${ }^{11}$, afirma Luiza; o en el caso de $A$ Família Albergaria (1874), que novela el período comprendido entre la muerte del rey D. João VI en 1826 y el final de la guerra civil en 1834, la presentación del personaje se inicia con esta distinción: "O rei estava sentado n'uma poltrona de velludo carmezim encimada pela corôa real/ $>^{12}$. En Maria da Fonte, de Rocha Martins, el narrador alude al infante con idéntico título.

En el caso de D. Pedro, su título nobiliario es el de emperador. Los narradores se refieren a él en su condición de emperador del Brasil y no como rey de Portugal, ya que la corona residía efectivamente en su hija, D. ${ }^{a}$ Maria II da Glória, tras la renuncia de su padre, que no podía mantener una corona dual: «O imperador estava radiante $»^{13} \mathrm{O}$, "O imperador tem vontade de ferro $»^{14}$.

El hecho de que los personajes sean caracterizados con sus nombres propios concreta su identificación como miembros de la familia real, mientras que el uso del título nobiliario, rey o emperador, sitúa al lector en un momento concreto de la historia de Portugal, con la perspectiva añadida del conocimiento de los aconteci-

\footnotetext{
10 TorReZÃo, G., A Família Albergaria. (Entre 1824-1834). Romance Histórico Original, Lisboa, Lucas \& Filho editores, 1874, pág. 224.

11 Soares, F. P. C., Luiza e Júlia. Romance Histórico que Comprehende o Tempo do Dominio de Dom Miguel, Lisboa, Imprensa Novesiana, 1845, pág. 87.

12 Torrezão, G., A Família Albergaria..., op. cit., pág. 200.

13 Galo, A. da S., Mário. Episódios das Lutas Civis Portuguesas de 1820-1834, s.l., Arcádia, s.d., pág. 349.

14 Torrezão, G., A Família Albergaria..., op. cit., p. 224.
} 
mientos que convirtieron a D. Pedro en emperador y su empeño en conservar el trono de Portugal en manos de su heredera directa frente a las pretensiones absolutistas encarnadas en su hermano, el infante D. Miguel. Se cumple así el principio de objetividad y verosimilitud que anima la construcción de toda novela histórica, aunque la filiación netamente liberal de los escritores trasluce también en el uso de este tratamiento de cortesía. En Mário (1867), por ejemplo, se alude significativamente a D. Miguel como «o príncipe». El narrador se resiste a utilizar con él el título de rey, que usurpaba, y tampoco se refiere a él como «infante», el título reservado para los hijos varones de la monarquía portuguesa. La opción por el genérico «príncipe» es una forma de mantener la filiación real de $D$. Miguel sin hacerlo partícipe de la alta dignidad que como miembro de una familia reinante le correspondería.

\subsection{La caracterización física}

Es en la descripción del físico el aspecto en el que los rasgos distintivos de ambos infantes se oponen con mayor nitidez. Éstos atañen tanto a los rasgos fisonómicos como a la indumentaria. La exposición de ambos elementos se realiza de forma pormenorizada, ya que para el narrador el carácter de los personajes se proyecta y refleja en un visual propio.

En el caso de D. Miguel, su indumentaria fijó la apariencia del personaje como ya lo había hecho con su padre, el rey D. João: «calções de ganga amarella, copiados de $D$. João $V I »^{15}$. El personaje de Jorge, que es el receptor de este vestuario, es un personaje negativo, un absolutista, que queda definitivamente caracterizado cuando el narrador de Os Bravos do Mindelo (1906) afirma que «(..) caprichava em vestir grosseiramente á D. Miguel»"16. El uso del adjetivo "grosseiro» es intencionado por parte del narrador. En portugués significa «pessoa que não tem boas maneiras, educação, delicadeza; pessoa que se comporta de modo considerado indecente, depudorado" ${ }^{17}$. En español "grosero, basto, ordinario; descortés, inmoral, inculto, rústico", entre las diferentes acepciones con las que se puede traducir. El autor describe profusamente esta forma de vestir, que condiciona también los atributos masculinos del rostro: «(...) jaqueta de alamares, cinta, calção, botas de prateleira, boné azul, cabello puchado para as fontes, cara rapada, porque o bigode denotava á legua constitucional».

Entre todos los adjetivos con los que se describe al personaje, llama la atención la calificación de "ordinario", que significa "contrapuesto a noble, plebeyo",

15 Fonseca, F. da, Os Bravos do Mindello. Romance Histórico, Lisboa, Livraria Editora Viúva Tavares Cardoso, 1906, pág. 29.

16 Ídem, pág. 38.

17 Dicionário da Língua Portuguesa Contemporânea da Academia das Ciências de Lisboa, Lisboa, Academia das Ciências de Lisboa/ed. Verbo, 2001. 
además de «común, regular y que sucede habitualmente; bajo, basto, vulgar y de poca distinción; que no tiene grado o distinción en su línea»18. Se destaca así la falta de elegancia del personaje en el vestir que lo pone en relación con el pueblo, una particularidad a la que se alude de forma sistemática en todas las referencias a D. Miguel. Obsérvese la descripción que de él hace Luiza en Júlia e Luiza: «(...) confunde-se com os lacaios que o seguem no alinho e aceio, e até no ar, porque usa um chapéo armado, mettido de través até os olhos, trazendo sempre um grande páo na mão enfiado em uma correia que Ihe prende no pulso»19.

Luiza alude, veladamente, al desaliño que caracteriza a D. Miguel. En este sentido, un elemento a tener en cuenta es la moda en el rostro, con la presencia o ausencia de bigote y barba. Llevar la cara rasurada indicaba afección al absolutismo, mientras el bigote y la barba eran propios de los liberales. $Y$ en efecto, la iconografía de ambos infantes presenta siempre a un joven D. Miguel completamente afeitado, mientras D. Pedro luce junto al bigote, una tupida barba. Representaciones posteriores nos presentan a D. Miguel de Bragança, ya en una madurez cercana a la ancianidad, mostrando los atributos tenidos por liberales, muy lejos de los retratos de juventud. También las novelas se hacen eco de esta evolución en su aspecto externo, como ocurre en Terra Prometida (1918): «Ela conservava perfeita memória (...) daquele homem triste, cuja barba grisalha Ihe dava um aspecto de ancianidade aos cuarenta anos ${ }^{20}$.

Pero a pesar de la apariencia, tan poca agraciada en su vestuario, de la falta de aseo, el aspecto físico de D. Miguel suscita, por lo general, las simpatías de los narradores. Véanse a continuación los siguientes fragmentos, tomados de Mário y A Familia Albergaria, donde se realiza la presentación del personaje: «Era este um homem de 29 anos, pois que nascera a 26 de Outubro de 1802. A sua estatura era um pouco mais baixa do que a regular. Tinha ombros largos, peito saliente, músculos bem desenvolvidos, energia e elegância nos movimentos. O rosto era comprido e iluminado por olhos formosos, grandes e expressivos" 21 .

"Contava então 28 annos. Era sympathica e espressiva a sua physionomia. Rasgados e eloquentes olhos animavam-Ihe o rosto correcto e oval: musculos de aço, peito largo e saliente, cabeça nobre, corpo bem constituido attestavam a riqueza d'aquella organisação, esterilisada á falta de noções moraes e intellectuaes" "22.

La influencia de Mário, novela a la que corresponde el primer párrafo, en A Familia Albergaria, de dónde está tomado el segundo, se hace patente en esta descripción del infante D. Miguel, pero se verifica con mayor firmeza en el retrato de D.

18 Vid. todas estas acepciones en Diccionario de la Lengua Española, Real Academia de la Lengua Española, Madrid, 21. ${ }^{\text {a ed., } 1992 .}$

19 SoARes, F. P. C., Luiza e Júlia..., op. cit., pág. 88.

20 Pimentel, A., Terra Prometida. Romance, Lisboa, Guimarães \& C. ${ }^{a}$ - Editores, 1918, pág. 15.

21 GaIO, A. da S., Mário..., op. cit., pág. 111.

22 Torrezão, G., A Família Albergaria..., op. cit., pág. 200. 
Pedro. Se trata de la descripción de un busto alargado. La imagen no nos permite contemplar al personaje de pie, aunque Silva Gaio hace una breve referencia a su estatura. Los narradores nos presentan al personaje en el mismo momento de su vida, justo antes de llegar a la madurez y, en ambas descripciones se insiste en su belleza física, presentando ante el lector a un hombre varonil en sus atributos físicos, con particular atención para los ojos y el pecho, aquellos elementos del cuerpo que presentan una mayor expresividad y traslucen mejor el carácter del personaje. El objetivo es suscitar la simpatía en el lector, de la que sin duda también participan los narradores.

En contradicción con su representación literaria, la iconografía que de él se conserva proyecta una imagen bien distinta. Resulta bastante extensa si tenemos en cuenta lo exiguo de su protagonismo político, fundamentalmente entre 1828 y 1834, pero en este período su figura se reproduce hasta la saciedad en todo tipo de objetos ${ }^{23}$. Una de las imágenes más conocidas es el retrato pintado por Giovanni Ender, que se conserva en el palacio de Queluz. Es a este retrato al que se refiere el narrador de Ressurreição dos Mortos, la única vez que aparece en las novelas que venimos tratando. La imagen aparece en una capilla, "quadra rectangular, entre a sala de visitas e a livraria, ocupada por um altar de talha dourada em que se venera a Senhora da Conceição, e conjuntamente o mais fiel dos seus vassalos: D. Miguel, o de Giovanni, reprodução do retrato histórico de Queluz, em que o filho de Carlota Joaquina, alto, franzino, farda constelada, mão direita sustentando o capacete emplumado, soberbo de elegância marcial, parece impor à História o cancelamento da fama de toreiro e de brigão que sagrou entre os do seu povo»"24.

No deja de ser significativa la colocación del retrato del infante junto al de la Virgen, subrayando las características mesiánicas que lo acompañaron, como ya notara Oliveira Martins en Portugal Contemporâneo. ${ }^{25}$ Según António Machado Pires, él fue el primero en valorar el sebastianismo desde este punto de vista al interpretar el miguelismo como propicio para la creación del mito mesiánico. ${ }^{26}$

Pero si D. Miguel es un hombre agraciado físicamente, ¿qué es lo que hace de él un personaje negativo, tal y como su vestimenta nos hace percibir? Los intelectuales de la segunda mitad del siglo XIX, sensibles a la idea de la educación social y política, ofrecen una explicación simple: lo que hizo del infante un personaje nefasto al desarrollo del país fue su instrucción, o más propiamente, la falta de ella. Guiomar Torrezão, al finalizar el retrato del infante en A Familia Albergaria, algo nos hace intuir, cuando habla de su falta de nociones morales e intelectuales, pero

23 Vid. SILva, A. B. M. da, Miguelismo..., op. cit., especialmente cap. 5 «Iconografia», págs. 317-334.

24 Costa, S., Ressurreição dos Mortos. Na Terra do Vinho I. Romance, Porto, Editorial Alice Félix \& C. ${ }^{a}$ Ltd. $^{a}$, 3. $^{\text {a }}$ ed., 1955, págs. 32-33.

${ }^{25}$ Oliveira Martins, J. P., Portugal Contemporaneo, 3. ${ }^{a}$ ed. (posthuma) e com as alterações e additamentos deixados pelo auctor, Lisboa, Livraria de Antonio Maria Pereira, ed., 1895, pág. 84.

26 PIREs, A. M., D. Sebastião e o Encoberto. Estudo e Antologia, Lisboa, Fundação Calouste Gulbenkian, 1982, págs. 94-96, cit. por SiLVA, A. B. M. da, Miguelismo..., op. cit., pág. 222. 
es Silva Gaio quien nos esclarece, una vez más, a respecto de la educación que el infante recibió durante su niñez. El narrador de Mário alude a ella en los siguientes términos: "Por tal modo fora desleixada a sua educação que bem podia dizer-se que nenhuma tivera. Dentro daquele crânio, cuja forma tinha nobreza, habitava um espírito sem cultura; e por isso era então como sempre fora, dirigido com facilidade por todas as ambições que se aproveitavam da sua qualidade de infante. Como os filhos ignorantes de muito morgado em Portugal, imaginava que acima de tudo estava o seu nascimento ilustre, e nunca a sã lição Ihe dissera o que a história conta dos príncipes mandriões ${ }^{27}$.

La responsable de la educación de los infantes es, para los liberales, la reina $\mathrm{D}$. ${ }^{\mathrm{a}}$ Carlota Joaquina. Como sucederá con sus hijos, la historiografía liberal hace de ella el reverso de D. João, su marido. En Mário, se describe al rey como un «homem bom, com alguma inteligência, nem sempre isenta de velhaca simpleza, mas indolente e nulo". El mismo narrador justifica en esta sencillez y en un exilio placentero en Río de Janeiro, su incapacidad de «pecador» para acoger nuevas ideas ${ }^{28}$. Ya la reina, hermana de Fernando VII y, por lo tanto, infanta de España, es algo bien distinto. A pesar de llegar a Portugal siendo una niña para desposar al rey D. João $\mathrm{VI}$, nunca dejó de ser considerada una extranjera. $Y$ es este hecho el que marca la diferencia respecto al resto de los miembros de la familia real. Tampoco su papel como reina y madre es valorado por los liberales, que de algún modo la responsabilizan de la situación política del país. Obsérvese el siguiente fragmento tomado de Mário, donde el narrador hace un demoledor retrato de D. ${ }^{a}$ Carlota, atacándola en esta triple faceta de madre, reina y esposa: «Má mãe, que não olhou pela educação de seus filhos; má rainha, que só fomentou discórdias; atrabiliária esposa do infeliz D. João VI; funesto presente da terra de Espanha!, 29

De ahí que D. Miguel sea, a pesar de todo, una figura relativamente bien tratada por los narradores. Su conducta se justifica como deudora de una falta de educación que en absoluto es imputable a él, sino a su madre: «A senhora $D$. Carlota Joaquina, indole ambiciosa e turbulenta, cuidando mais da política que da educação dos filhos, soprara no coração de D. Miguel o facho da rebelião, incitandoo a conspirar contra o pae!! ... ${ }^{30}$

D. Pedro es en todo opuesto a su hermano. Las novelas han sido parcas en la recreación de este personaje, del que poseemos, sin embargo, un acabado retrato. Criado junto al infante D. Miguel, disfrutando de una infancia feliz en S. Cristóvão, marcada por una escasez de estudios que se compensaba con ejercicios físicos corporales ${ }^{31}$, la influencia de D. ${ }^{a}$ Carlota Joaquina no hizo mella en él. Físicamente, «(...) era um homem de estatura mais que mediana, pálido, com bas-

27 GAIO, A. da S., Mário..., op. cit., pág. 111.

28 Ídem, pág. 276.

29 Ídem, pág. 113.

30 Torrezão, G., A Família Albergaria..., op. cit., pág. 200.

31 GAIO, A. da S., Mário..., op. cit., pág. 277. 
tantes sinais de bexigas, que mal encobria a barba comprida que usava. Tinha uma bela fronte e um olhar altivo " 32 .

El narrador había predispuesto a favor al lector al iniciar la descripción con un "O imperador estava radiante», antes de proceder al dibujo del personaje. Lo conciso pero a la vez concreto de la descripción, hizo que fuese reproducida con algunas pequeñas variantes por Guiomar Torrezão en A Família Albergaria: "Longa e cerrada barba preta emmoldurava o pallido, bexigoso e energico rosto do imperador; o olhar firme, penetrante e altivo encarava de frente a pessoa a quem se dirigia e costrangia a muitas vezes a baixar os olhos " 33 .

Obsérvese cómo los retratos de los infantes son el reverso opuesto de uno y otro. D. Miguel y D. Pedro son contrarios en estatura, aseo e indumentaria. Curiosamente, varias referencias destacan la frente de D. Pedro: «de heroe» ${ }^{34}$, «bela», acompañada de un "olhar altivo»"35, tal y como se espera de una persona de alta dignidad. Pero lo que quizá llame más la atención es que mientras en D. Miguel prima lo físico frente a lo psicológico, en D. Pedro es justo al contrario, y los narradores están más preocupados por mostrarnos los rasgos de su carácter que su apariencia externa.

\subsection{La caracterización psicológica}

Junto al retrato físico, las novelas ofrecen de los infantes un retrato psicológico. Si en el caso de D. Pedro las referencias a su fisonomía son escasas aunque precisas y acompañando un rasgo de su personalidad, los narradores se extienden más a la hora de caracterizar al personaje en términos psicológicos. Al mismo tiempo, la presentación de su personalidad se hace por oposición con D. Miguel. Compárense los siguientes fragmentos tomados de Mário. En el primer caso el narrador nos describe a D. Pedro, mientras que en el segundo se nos habla de D. Miguel: "Quando um nobre sentimento Ihe fazia pulsar o coração, o seu rosto revelava o estado da alma, e era tão simpático e atraente como poucos. Com um génio arrebatado, violentíssimo, se estava encolerizado, nem as palavras, nem os actos eram próprios da sua posição. Ele mesmo conhecia estes defeitos, e os confessava. De uma actividade prodigiosa, por meio dela, e do exemplo que a todos dava como soldado, foi um salvador da causa liberal».

«À obstinação com que avaliava o que Ihe haviam dito ou diziam que eram direitos seus, juntava o deplorável, senão contraditório, hábito de admitir, nos seus divertimentos, homens de baixa condição e de baixíssima índole. Os seus prazeres eram preparativos para touradas; corridas violentas sobre cavalos domados e

\footnotetext{
32 Ídem, pág. 349.

33 ToRrezÃo, G., A Família Albergaria..., op. cit., pág. 255.

34 Ídem, pág. 224.

35 GAIO, A. da S., Mário..., op. cit., pág. 349.
} 
guiados com suprema elegância e mestria; rápidos jantares de grosseiras comidas, no campo, em qualquer parte, longe do Paço. Nunca uma ideia de artista; nunca um pensamento grande; nunca a necessidade de prazeres mais finos, mais intelectuais, acordaram no ânimo daquele real companheiro de campinos, de Leonardos, de Josés Veríssimos e de tantos outros!»’36.

En la caracterización psicológica de ambos infantes hay que señalar una diferencia significativa. D. Pedro es descrito desde el punto de vista del carácter, pero en D. Miguel vuelve a insistirse en lo desafortunado de su educación. Es decir, si en el caso de D. Pedro estamos ante características innatas, en D. Miguel nos hallamos en presencia de una conducta aprendida. Subyace aquí una idea de predestinación de la fortuna del país, ya que dado el carácter de D. Pedro resulta congénita su filiación al liberalismo, mientras en D. Miguel la tendencia al absolutismo podría haber sido evitada de haber recibido una educación más refinada.

Por otro lado, el narrador no idealiza la figura de D. Pedro. Destaca en él el hecho de poseer un temperamento fuerte, a veces incluso agresivo, que se traducía en una cierta violencia verbal y física. No obstante, la nobleza con la que se reviste al personaje reside en la propia aceptación de una conducta cuestionable, y en la justificación de un estado de ánimo que es siempre transitorio. De ahí que incluso tan negativo talante se traduzca en algo positivo para la causa liberal: «(...) era ambicioso de todas as glórias, e bravo, temerário mesmo ${ }^{37}$, que en esta cita reviste las características de la propaganda subliminal. El sintagma «ambicioso de todas as glórias", incluido en un contexto bélico de enfrentamiento entre absolutistas y liberales, tiene además otra lectura: la de coincidir con el nombre propio de la reina-niña, D. ${ }^{a}$ Maria II da Glória, reforzado por el uso del pronombre indefinido «todas». La ambición de D. Pedro es positiva, pero también pragmática y real, porque la utiliza no en beneficio propio, sino en el de su heredera y, por lo tanto, como servicio al país.

Al emperador lo adornan otras cualidades, que lo hacen cercano y familiar para quienes lo rodean. Pero a diferencia de D. Miguel, que basaba esa accesibilidad en compartir con el pueblo llano aficiones tenidas por rudas, toscas o poco elegantes, D. Pedro es, ante todo, un hombre afectuoso: «Recebeu Saldanha com a mayor afabilidade (...)» ${ }^{38}$, en todo denotando magnanimidad: « $D$. Pedro acedeu e despediu, com um olhar agradecido, o seu chefe de estado-maior e os que o acompanhavam»39.

\footnotetext{
36 Ídem, págs. 349 y 111-112, respectivamente.

37 ĺdem, pág. 349.

8 íbidem.

39 Ídem, pág. 348.
} 


\subsection{La caracterización a través de las acciones}

Este tipo de caracterización complementa los rasgos psicológicos. Se trata de la plasmación de las tendencias innatas de los personajes. En un contexto bélico como el que mayoritariamente relatan las novelas, la actitud ante la guerra diferencia a ambos personajes. Significativamente, no es el narrador el que describe la actitud de los infantes ante el campo de batalla, sino otro personaje: «- Enquanto o senhor $D$. Pedro offerece o peito ás balas, continuou Eduardo, pessoalmente risca os planos de campanha e incansavel dirige as manobras, incutindo-nos a todos o fogo que Ihe inflamma o animo, o que faz o senhor D. Miguel?!... Vê a guerra em distancia, por um oculo, encommenda-se ás rezas conventuaes, escuta e diz inepcias aos capitães-móres, demitte commandantes, e nas horas vagas merenda com os campinos!!... Hão-de convir que é detestável! »40

Mientras D. Pedro nos aparece descrito como un jefe militar, un estratega que dirige su ejército hacia un objetivo definido, la instauración del liberalismo, D. Miguel carece de motivaciones políticas y militares. De ahí que la guerra le resulte totalmente ajena, dejando todo el protagonismo para sus militares, ante los cuales se convierte en "cêra malleavel que nas mãos d'aquelles homens adquire fórmas grotestas e antipathicas!...»41 Las novelas se esfuerzan en presentar al infante como un ser manipulado por intereses externos, los que defienden su madre y políticos desleales: "O principe $D$. Miguel deixava-se fácilmente dominar, suppondo sempre que dominava os outros; esse senão, que em diversas circumstancias figuraria de virtude, proveniente n'elle da ignorancia da arte de reinar, e a fatalidade que o rodeiou de crueis e inhabeis conselheiros, aluiram-Ihe o throno!»42, que acaban finalmente por traicionarlo: «(...) depois pagaram-Ihe com felonias $e$ traições vis muitos daqueles que protegeu, elevou e acarinhou "43.

La actitud ante la guerra no es lo único moralmente reprobable en D. Miguel. Maria da Fonte nos presenta otra, que refiere la falta de caballerosidad del infante. Está relacionada con su gusto por compartir su tiempo con personas no sólo de baja condición social, sino por frecuentar amistades de integridad cuestionable. En esta novela, que se desarrolla durante los años de su reinado, aparece intentando violentar a una dama. Ante su estupefacción, D. Lenia se enfrenta abiertamente con él. El narrador describe en ese momento a D. Miguel como un «homem dominado de bestiaes instintos, habituado ao convivio com os picadores de touros e gente da ralé». ${ }^{44}$ Pero como ocurre en otras novelas, también en este caso el narrador ofrece para la actitud de D. Miguel una explicación que la justifica. En este caso, los responsables de esta conducta son cuatro: la falta de educación, sus

\footnotetext{
40 Torrezão, G., A Família Albergaria..., op. cit., pág. 249.

41 Íbidem.

42 ĺdem, pág. 201.

43 GaIO, A. da S., Mário..., op. cit., pág. 114.

44 Martins, R., Maria da Fonte..., Vol. I, Lisboa, João Romano Torres \& C. ${ }^{\text {a }}$ ed., s.d., pág. 276.
} 
amistades, la reina D. Carlota Joaquina y..., la propia D. Lenia: «No emtanto esse rei, creado sempre entre homenagens, amigo dos toureiros, lidando com individuos de parca educação, dos quaes adquirira os vicios, como da mãe herdára os ruins apettites, guardava ainda alguma coisa de bom no fundo do coração; seria capaz de se enternecer, de ter piedade d'aquella mulher, se ella, em vez de lhe falar tão altivamente, Ihe caisse aos pés supplicante e humilde». ${ }^{45}$

\subsection{La caracterización a través de otros personajes}

Se trata de un tipo de caracterización indirecta, en la que los personajes exponen la percepción que tienen de otros. Por ejemplo, para Luiza, D. Miguel no es feo, aunque subraya una mirada desconfiada y ferina, impropia de una persona de tan elevada alcurnia ${ }^{46}$. En el siguiente diálogo, Eduardo y Álvaro conversan, lo que permite que conozcamos que $\mathrm{D}$. Pedro es un hombre honrado, de palabra:

«(Eduardo) - Parece-te que o imperador cumplirá o que prometteu?

(Álvaro) Ha de cumprir! O imperador tem vontade de ferro» ${ }^{47}$.

En la misma conversación, ambos personajes caracterizan por oposición a D. Miguel:

«-O reverso do irmão, acudiu Alvaro, que nenhum pensamento nobre e elevado comprende!...

-Elle sim!... Todo o tempo é pouco para caçar...

—E para mandar matar gente! » 48

También hemos señalado la descripción de la diferente actitud bélica de los infantes como un tipo de caracterización indirecta.

Significativamente, la conducta de D. Miguel, como hombre y como rey, es la que permite una evaluación más extensa, debido a su propio cuestionamiento. Los autores son liberales que la enjuician para poder proceder a un objetivo de profilaxis política, utilizando incluso la estrategia de la caracterización por los realistas. En el siguiente fragmento, el narrador nos ofrece la percepción que el absolutismo tenía de D. Miguel. Ésta es la opinión de un personaje, Jorge Pinto, que en la novela simboliza a los absolutistas: "Jorge Pinto conhecia bem o príncipe, e dizia que ele não era um mau homem; e acrescentava que não é mau quem quer. Dizia que o levavam para os actos de rigor com a mesma facilidade com que o levariam para os de clemência; que se, como seu pai, não recusava assinar sentenças de morte, era porque tinha menos medo, menor longanimidade e menor saber do que

\footnotetext{
45 Ídem, pág. 274.

46 SoARes, F. P. C., Luiza e Júlia..., op. cit., págs. 87-88.

47 Torrezão, G., A Família Albergaria..., op. cit., pág. 224.

48 Íbidem.
} 
aquele; e porque the pregavam com o exemplo de outros reis, e com a palavra "lei», que produzia nele o assombro que produz nos saloios. Dizia que os seus mais atendidos conselheiros Ihe haviam ensinado o caminho que muito bem conheciam de o terem trilhado, que assim como o príncipe jurara a carta de 1826, assim a tinha $(m)$ jurado, com proveitos e honrarias, o bispo de Viseu... (...) Concluía que, para governar um país, e assentar uma dinastia, mais valiam, juntas à sua grandeza de ânimo, as cóleras terríveis de $D$. João Il do que os medos de $D$. João VI e a reconhecida incompetência de D. Miguel" ${ }^{49}$.

Pero quizá el tipo de caracterización indirecta más reveladora sea la que realizan los autores de mano de los narradores. Ahora no estamos sólo ante la construcción de un personaje, sino ante un juicio de valor sustentado en el hecho de que las novelas tienen un valor pedagógico. Por eso, estas opiniones adquieren la categoría de dictámenes. Los autores, transformados en historiadores, realizan el análisis de un período histórico concreto para el que los narradores ofrecen una explicación que no se pretende universal. Autor y narrador se solapan en la exposición de sus convicciones. Véase el siguiente fragmento tomado de Mário, en el que se valora la actuación de D. Miguel después de haberlo hecho Jorge Pinto. En la novela funciona como un aparte y, se individualiza del desarrollo de la ficción mediante espacios en blanco. La cita es larga, pero merece la pena transcribirla íntegra: «Nós, avaliando este príncipe mais de trinta anos depois do terrível comendador, pensamos também que não era de natureza incorrigivelmente má, que não era uma índole perversa a daquele rei que foi resignado e paciente no exílio, e depois cuidadoso chefe de família. Pensamos que não têm valor histórico as pinturas apaixonadas que apresentaram D. Miguel como um Tiberio. Não o foi. Fez como faziam muitos outros imperantes. (...) Pensamos que o príncipe, que fez por tantos anos a desgraça da sua pátria, podia ter sido, com outros conselheiros e outra mãe, um homem sem responsabilidades graves, um príncipe como há muitos. Entendemos que foi o pior dos cabeças de partido, porque não tinha instrução, nem grandeza de ideias, nem reflexão, nem energia, para tão alto posto. Acanhado representante de um passado incompatível com os anos em que reinou de facto, nem conheceu o que nesse passado havia de grande, nem teve olhos para compreender o presente.

\section{Como infante, foi o instrumento cego da camarilha de sua mãe. (...)}

Como chefe de um partido, foi uma real mediocridade, que muitas lágrimas, muito luto, muita orfandade, amaldiçoaram.

Com razão; porque, sem necessidade nem consciência, e como uma carta jogada por Wellingtons, Vielles, Metternichs, e ambiciosos de cá, veio mudar a ordem de coisas que acabava de prestar juramento.

Com razão; porque se ele não animasse, quando chegou de Viena em 1828, os despeitos, os rancores, as ignorâncias dos que choravam pelos direitos banais,

49 Galo, A. da S., Mário..., op. cit., pág. 112. 
dos que malevolamente confundiam princípios religiosos com princípios políticos, seria em pouco tempo dissipada a nuvem dos descontentes, pois que Ihes faltava a alavanca em que esperavam.

(...) Com razão; porque se (como em 1828 começaram a proclamar, com anuência do príncipe) seu irmão mais velho, o imperador do Brasil, não podia dar uma carta a Portugal, nem governá-lo, não deveria ele, infante, aceitar-Ihe traiçoeiramente o lugar-tenência nem jurar essa carta»50.

\subsection{La caracterización a través del lenguaje y de la voz}

En directa conexión con su psicología, el uso de un determinado lenguaje denota la personalidad de los personajes. En los casos de D. Pedro y D. Miguel, los narradores no los distinguen a través del lenguaje. Ambos infantes se crían en el mismo contexto y ni siquiera la convivencia de D. Miguel con toreros y gente de baja clase condiciona un lenguaje descuidado. Por eso, las referencias que tenemos son de carácter indirecto, es decir, nos son transmitidas por el narrador o por los personajes. De D. Miguel sólo se nos comunica la percepción que Sofia Bacelar, la protagonista de Terra Prometida, tiene del infante, del que recuerda su «VOZ quente»"

El lenguaje con el que se caracteriza a D. Pedro en todo denota el militar que era, y así, por ejemplo, se nos informa de que era poseedor de «linguagem nobre e guerreira»52. Además: "Quando nos dirige a palabra, referindo-se á pátria, á filha, ou á liberdade, os seus tres ideaes, vê-se irromper a chama do enthusiasmo e illuminar-Ih'a!..., ${ }^{53}$

Tampoco la reina D. ${ }^{a}$ Carlota Joaquina escapa a esta caracterización por parte de los narradores. Ya se nos había informado sobre su "génio bulhento e inquieto", que acompaña de una charlatanería constante y una gesticulación extrema. Además de hablar "em altas vozes», utilizaba "palavras mal soantes», que en nada revelaban el alto linaje de que procedía. La feliz niñez que disfrutaban los infantes en su exilio de Río de Janeiro se ve así condicionada por el carácter de la reina, que vuelve a aparecer como la directa responsable de la falta de educación de sus hijos. El narrador introduce además la siguiente anécdota, muy reveladora del carácter de D. ${ }^{a}$ Carlota: «Um dia perguntou uma das senhoras infantas por que tinham quase todos os novos titulares nomes de drogas de botica. A resposta foi uma severa correcção de sua mãe que estava de maus humores, e uma gargaIhada mal contida de todos os circunstantes,"54.

50 Ídem, págs. 113-114.

51 Pimentel, A., Terra Prometida..., op. cit., pág. 15.

52 GAIO, A. da S., Mário..., op. cit., pág. 349.

53 Torrezão, G., A Família Albergaria..., op. cit., pág. 225.

54 GAIO, A. da S., Mário..., op. cit., pág. 277. 


\section{EL ÉXITO DE LA CARACTERIZACIÓN LITERARIA}

La imagen que de los infantes D. Pedro y D. Miguel se transmite en la novela histórica del siglo XIX tuvo un reflejo en la historiografía posterior. En fecha tan reciente como 1881, el historiador del liberalismo por excelencia, Oliveira Martins, publica Portugal Contemporâneo, donde aborda la instauración del régimen liberal en Portugal. En el apartado dedicado a la "Carta Constitucional», el autor introduce el análisis de la figura del infante $\mathrm{D}$. Miguel, al que pinta como un joven inconsciente que cae en la trampa de aduladores que lo hacen creer que es el Mesías salvador ${ }^{55}$ de un país que camina inexorablemente hacia su destrucción. Pero lo más significativo es que Oliveira Martins recoge todos los tópicos con los que se había caracterizado al infante. En el siguiente fragmento, el historiador-narrador nos lo presenta metafóricamente descrito como un toro, una imagen muy significativa, ya que como hemos visto se pintaba a D. Miguel frecuentando la amistad de toreros: «(...) e elle, envolvido na nuvem inebriante do triumpho, restaurado á sua terra, ás suas antigas affeições, violento e simples, servo ingenuo das impressões, incapaz de as dirigir por um raciocinio frio; elle, o infante, acclamado e ungido por um clamor de vozes, allucinado, como a fera cega pela capa vermelha do toureiro, estacou, tremeu, e converteu-se - decidido a investir com furia, baixando a cabeça, cerrando os olhos, rugindo uma ameaça longa... "\$6

No es el único que nos presenta a D. Miguel como la imagen viva de la decadencia del país. Oliveira Martins se hace eco de una publicación que circulaba por esos años, la Biographia do chamado infante D. Miguel, que tenía como objetivo contrarrestar la imagen que José Agostinho de Macedo, miguelista convicto, y su escuela, proyectaban de él. Oliveira Martins afirma que en el volumen mencionado: «(...) o usurpador era pintado como filho adulterino, bebedo em permanência, vomitando pelo paço, atirando ao alvo de pretos no Brazil, analphabeto, assassino; e da rainha-mãe dizia-se ahi, não sem razão, ser uma Messalina mais infame ainda, e mais impudica do que a romana». ${ }^{57}$

A pesar de estas descripciones, la figura del infante $\mathrm{D}$. Miguel es sólo relativamente maltratada, ya que como vemos, los narradores o los personajes proceden a una justificación casi inmediata. Su recuperación es bastante temprana. Se inicia en Mário, cuya primera edición data de 1867, donde Silva Gaio introducía la siguiente prolepsis, muy elocuente, sobre el futuro del infante: "Veio depois 0 cortejo dos desenganos, das ingratidões, e com ele o amargo pão do exílio. $E$ como exilado, e como pai, foi digno; e maior na sua pobreza, do que nunca o havia sido como infante, nem como rei» ${ }^{58}$.

\footnotetext{
55 Sobre el mesianismo de D. Miguel, vid. Silva, A. B. M. da, Miguelismo..., op. cit., págs. 293-315.

56 Oliveira Martins, J. P., Portugal Contemporaneo..., op. cit., pág. 84.

57 Ídem, pág. 102.

58 GAIO, A. da S., Mário..., op. cit., pág. 114.
} 
La rehabilitación total se producirá algún tiempo después, con la publicación en 1872 de Terra Prometida, de Alberto Pimentel. El autor construye una trama con un eje temático, el que narra la historia de D. João Bacelar y su hija, Sofia de Haucourt Bacelar, cuya vida transcurre casi en paralelo con la de D. Miguel. La novela utiliza como marco cronológico la segunda mitad del siglo XIX, los años dominados por la política de Regeneração de Fontes Pereira de Melo. Aquí los absolutistas viven de forma discreta y placentera en Lisboa, en un círculo pequeño que recuerda siempre a un $\mathrm{D}$. Miguel exiliado en Austria, pero que no cuestiona la realidad vigente. Dos años más tarde, en 1874, Guiomar Torresão introduce en $A$ Familia Albergaria un párrafo que contribuye a la rehabilitación de la imagen de $D$. Miguel: "O exilio de $D$. Miguel porém, placido, resignado, constantemente devotado á esposa e filhos, responde pelo que o infante teria sido se outra mãe, outros conselheiros e outro destino houvesse tido " 59 .

Sin embargo, la imagen de la reina $D .{ }^{a}$ Carlota Joaquina no corre la misma suerte. El propio Oliveira Martins anota la expresión «no sin razón» en el demoledor juicio que hace de ella. D. ${ }^{a}$ Carlota siguió concentrando la responsabilidad de las atrocidades cometidas durante los años del reinado de D. Miguel, los asesinatos políticos, las persecuciones y el exilio que sufrieron los liberales. En el episodio de la Belfastada (1828), en el que las tropas liberales sufren la derrota contra D. Miguel, que inicia entonces sus años de reinado, se contaba que la reina se había dirigido al general Povoas, el comandante de las tropas realistas con las siguientes palabras: "Corte-me, corte-me cabeças! A revolução franceza cortou quarenta mil e nem por isso a população diminuiu».60

Además, las referencias que describen a D. ${ }^{a}$ Carlota como una mujer liviana son frecuentes en las novelas. En Maria da Fonte el narrador alude, por ejemplo, a una hija bastarda. ${ }^{61}$

59 Torrezão, G., A Família Albergaria..., op. cit., pág. 201.

60 Oliveira Martins, J. P., Portugal Contemporaneo..., op. cit., pág. 108.

61 Martins, R., Maria da Fonte..., op. cit., Vol. I, pág. 44. 